\title{
The influence of the principal instructional leadership on teacher's job satisfaction at vocational secondary schools
}

\author{
Hermi Kurnia *, Nurtanio Agus Purwanto (iD, Indah Fitoriyati \\ Universitas Negeri Yogyakarta. \\ * Corresponding Author. Email: hermikurnia8@gmail.com
}

\section{ARTICLE INFO}

\section{Article History}

Received:

6 July 2021;

Revised:

31 July 2021;

Accepted:

26 August 2021;

Available online:

7 November 2021

\section{Keywords}

Instructional

leadership;

Job satisfaction;

Vocational school

\begin{abstract}
This study aimed to discover the school principal instructional leadership influence on job satisfaction of vocational high school teachers in Sleman Regency, D.I. Yogyakarta. This type of research was ex-post facto with a quantitative approach. The questionnaire was conducted on 91 teachers (71,09\% response rate) to examine the influence of principal instructional leadership (X) on teacher job satisfaction (Y). Validation of the instrument used expert judgment and empirical test with the Pearson Product Moment correlation, 43 out of 43 items are declared valid. The instrument reliability test was applied by using Cronbach's Alpha. The results of the reliability test showed that all variables were declared reliable $(\alpha>0,7)$. A classical assumption test was done by testing normality, linearity, multicollinearity, and heteroscedasticity. Simple linear regression was used as data analysis to test the influence of the independent variable $(\mathrm{X})$ towards the dependent variable $(\mathrm{Y})$. The simple linear regression results indicate a positive and significant influence between the principal instructional leadership on teacher job satisfaction $(\mathrm{t}=13,329, \mathrm{p}=.000)$. The coefficient of determination value $\left(\mathrm{R}^{\wedge} 2\right)$ of 0,666 indicates that the principal instructional leadership influences teacher job satisfaction by $66,6 \%$. Meanwhile, the remaining $33,4 \%$ are influenced by other factors.
\end{abstract}

This is an open access article under the $\underline{\mathrm{CC}-\mathrm{BY}-\mathrm{SA}}$ license.

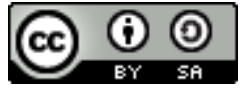

How to cite:

Kurnia, H., Purwanto, N. A., Fitoriyati, I. (2021). The influence of the principal instructional leadership on teacher's job satisfaction at vocational secondary schools. Jurnal Pendidikan Vokasi, 11(2), 171-181. https://doi.org/10.21831/jpv.v11i2.42193

\section{INTRODUCTION}

Teaching in the 21 st century has many challenges for teachers that make teachers have more roles in school to meet the expectations of students, parents, and society of educational needs. This statement is equivalent to the argument of Türkoğlu et al. (2017) also stated that expectation had become lifelong education needs by involving every competency such as research, critical thinking, problem-solving, group work, and information and communi-cation technology use, resulting in the significant change towards teacher's responsibility. Buluc and Demir (2015) stated that teachers' competency in a particular field and teacher job satisfaction had become a necessity in working achievement and organizational productivity. Teacher job satisfaction is an essential predictor to determine the accomplishment of the learning process. Türkoğlu et al. (2017) stated that job satisfaction is crucial for the teaching profession since a teacher must serve the students through the teaching process. Locke (1969) stated that job satisfaction is a pleasant condition resulting from positive emotion in work evaluation or work experience from an individual.

Job satisfaction is considered as an emotional response to someone's job, physical condition, and social, while the job's satisfaction concept is how satisfied someone is with the expectations of 
the job (Buluc \& Demir, 2015). Nuraini et al. (2015) perceives teacher job satisfaction as an active emotional response from teachers related to the teachers' feelings experienced on various work aspects with the indicators as in their work as teachers, supportive working conditions, salary/reward, supervision from the leader, and supportive co-workers. The results from the pre-survey questionnaires trial of job satisfaction to 30 teachers sample on one of the vocational high schools in Tempel district in 2020 reveals that the teachers who give job satisfaction evaluation with a low category are six people $(20 \%)$, teachers who give job satisfaction evaluation with a medium category are 13 people $(43,33 \%)$, and teachers who give job satisfaction evaluation with a high category are 11 people $(36,67 \%)$. The pre-survey data results reveal that most teacher job satisfaction evaluations percentage is in the medium category.

Based on the pre-survey results, it is found that the income of teachers, especially those who were not civil servants yet, can be said cannot fully meet the life needs. These results can be seen in the statement of teacher job satisfaction statement item on salary (item number 2) stated that economic needs are fulfilled from the salary of teaching works in school. Meanwhile, on average, teachers with non-civil servant status stated their assessments on a scale of (2) Moderately Agree and (1) Disagree. Salary is one of the determinants of teacher job satisfaction. Sufficient salaries allow teachers to feel satisfied with teaching work in school. This statement is proved by the study conducted by Rahayuningrum et al. (2019) that show salary has a positive influence on teacher job satisfaction at Vocational High School (VHS) PENDA 2 Karanganyar with the regression analysis results, with the $r$ count value $0,545>r$ table 0,301 which means salary has a significant influence on teacher job satisfaction. It means that an adequate salary will provide high job satisfaction to the teacher. Still, on the contrary, if the salary is not sufficient, then job satisfaction will also not be fulfilled. The results of other studies also show the same outcome, as stated by Hulmawiyah et al. (2018), where teacher compensation has a positive influence on job satisfaction of Vocational High School (VHS) 10 Malang teachers, both partially and simulta-neously (together with the principal leadership variable, and teacher work discipline).

The teacher's responsibility to fulfill learning administration also appears as a problem and causes the teacher's time management in preparing the learning material itself to be divided. Based on interviews with the deputy principal at one of the Vocational High Schools (VHS) in Tempel District, it was found that administrative activities outside of learning activities also took quite a lot of time for teachers. Hence, the teacher's time in implementing learning activities becomes less effective. It can be observed from the statement in the pre-survey results that have been conducted, "Teachers feel that working hours at school are effective." Some teachers stated that the assessment on a scale of (2) moderately agree and (3) agree. Time is one factor that determines effective learning; as Setyosari (2014) stated, good time management will produce an effective learning process.

The findings of the pre-survey in the field also show that the improvement of learning activities through various methods has not been tried or applied by all teachers. Some of the existing teachers are active in finding new methods and developments in teaching. However, there are still teachers who are less active in exploring methods in teaching. The teachers' effort in applying learning activities optimally is an aspect that can show the level of teacher job satisfaction for their work. This statement is in accordance with Cansoy et al. (2018) argument that teachers' belief in professional competence (in teaching) is essential in determining job satisfaction.

Skaalvik (2020) revealed that the school principal has a dominant role in developing a learning environment in school areas that affect teacher job satisfaction and student learning activity. The analysis of the effect of principal instructional leadership on teacher's perceptions conducted by Özdemir et al. (2020) revealed that there was a significant intermediate level relationship between the instructional behavior performed by the principal, and it is contributed positively to teacher's motivation and assignments, development of the students' ability to learn, and teacher self-evaluation skills about themselves and students.

Özdemir et al. (2020) argued that principal instructional leadership has consistently been proved to be an essential determinant of teacher self-efficacy perceptions. According to them, the instructional leadership that focuses on improving teaching and learning activities in schools is more effective on teacher self-efficacy than other leadership styles. Moreover, instructional leadership behaviors are essential in supporting students' academic success and making school staff adopt 
student-centered learning. Other research findings of Özdemir et al. (2020) claimed that instructional leadership behavior makes a positive contribution not only to teachers' behavior on curriculum implementation, diversification, and evaluation of teaching methods but also their morals, expectations, and task-oriented work. Özdemir et al. (2020) research added concrete evidence that instructional leadership can positively contribute to teacher self-efficacy and the curriculum, morals, and teacher integrity.

Table 1. The Framework of Instructional Leadership Work

\begin{tabular}{ll}
\hline \multicolumn{1}{c}{ Dimension } & \multicolumn{1}{c}{ Sub-dimension } \\
\hline Defining the school mission & - Framing school goals \\
& - Communicating school goals \\
& - Coordinating the curriculum \\
Instructional program management & - Supervising and evaluating the instruction \\
& - Monitoring the students' development \\
& - Providing learning activity time \\
Developing school learning climate & - Providing incentives for teacher \\
& - Promoting professional development \\
& - Maintaining high visibility \\
\hline
\end{tabular}

Hallinger and Wang (2015) explained that the instructional leadership management framework becomes valuable lens researchers use to conceptualize how instructional leadership is implemented in schools. Hallinger and Wang (2015) revealed that instructional leadership has a conceptual framework consisting of three dimensions: defining the school's mission, managing instructional programs, and developing a positive school learning climate. These dimensions are illustrated into ten sub-functions of instructional leadership, as displayed in Table 1.

The findings from the research on instructional leadership conducted by Hallinger and Wang (2015) showed effects on the following aspects: 1.) Effects of personal antecedents (such as gender, training, experience) and school context (school level, school size, school SES) on instructional leadership; 2.) Effects of instructional leadership on organizations (school goals and vision, expectations, curriculum, teaching, teacher involvement); and 3.) The indirect and direct influence of instructional leadership on students' achievement and various school outcomes. From the previous explanation, it can be concluded that instructional leadership is leadership that focuses on developing the school's vision/goals, learning programs, and school climate. Smith and Andrews (1989) believe that instructional leadership generally is categorized into four areas of strategic interaction between school principal and teacher which include: 1.) School principal as a resource provider; 2.) School principal as a learning resource; 3.) School principal as a communi-cator; and 4.) School principal as a visible presence.

Locke (1969) suggests that job satisfaction is a pleasant emotional condition due to the individual's job appraisal as an achievement of the job. While job dissatisfaction is an unpleasant emotional condition resulting from the individual's job appraisal, the achievement is obstructive. Both terms are the functions of the perceived relationship between what is desired from the job and what is perceived as supply and demand. According to Spector (1997), job satisfaction is an expression of a person's favorable or unfavorable about work and various aspects of his work. Job satisfaction is considered an overall feeling for the job or a constellation of attitudes related to various aspects of the job. According to Gruneberg (1979), job satisfaction refers to a person's emotional reaction to a particular job.

Gruneberg (1979) states that the Job Descriptive Index (JDI) is the most accurate instrument for measuring job satisfaction. The JDI rating scale is in the form of salary, people, promotion, supervision, and work, each of which consists of several items. Gruneberg (1979) stated that the main factors of job satisfaction are considered in the following aspects: 1.) Salary; 2.) Security; 3.) Workgroup; 4.) Supervision; 5.) Participation; 6.) Role conflict and ambiguity; and 7.) Organizational structure and organizational climate. Teacher job satisfaction has consequences on teachers' attitudes and behavior, both independently and through interactions with other factors (Dou et al., 2016). Job 
satisfaction plays an essential role in the overall commitment and productivity of the school organization. Nevertheless, teacher job satisfaction also significantly affects their commitment to the organization (Baluyos et al., 2019). Teachers who are satisfied with their work are also committed to working in the organization (Baluyos et al., 2019).

Based on the explanation above, it can be concluded that the activities of teachers in teaching are never free from obstacles and challenges. However, teachers still need to feel satisfied at work to create an effective organization or school. Based on the review of several research references, the authors believe that principal instructional leadership can affect teacher job satisfaction. This raises a question for the author to conduct research related to the influence of principal instructional leadership on job satisfaction of vocational high school teachers in Tempel District. This study aims to discover the principal's instructional leadership effect on teachers' job satisfaction at vocational secondary school in Tempel District, Sleman Regency, D.I. Yogyakarta.

\section{RESEARCH METHOD}

The researcher used ex post facto as a quantitative method and data collection techniques through surveys in this study. The researcher used a survey to know to what extent the instructional leadership affected teacher job satisfaction of vocational high schools in Tempel District. The research population was 128 teachers from five Vocational High schools in Tempel District. The sample was taken using a simple random sampling technique and calculated using Isaac and Michael formula. Therefore, the samples of 91 teachers were obtained. Moreover, the research instrument was in the form of a questionnaire and applied a Likert scale as the answer choices with a value range of 1-4. Each item was assessed with the following conditions: (4) Strongly Agree; (3) Agree; (2) Moderately Agree; and (1) Disagree.

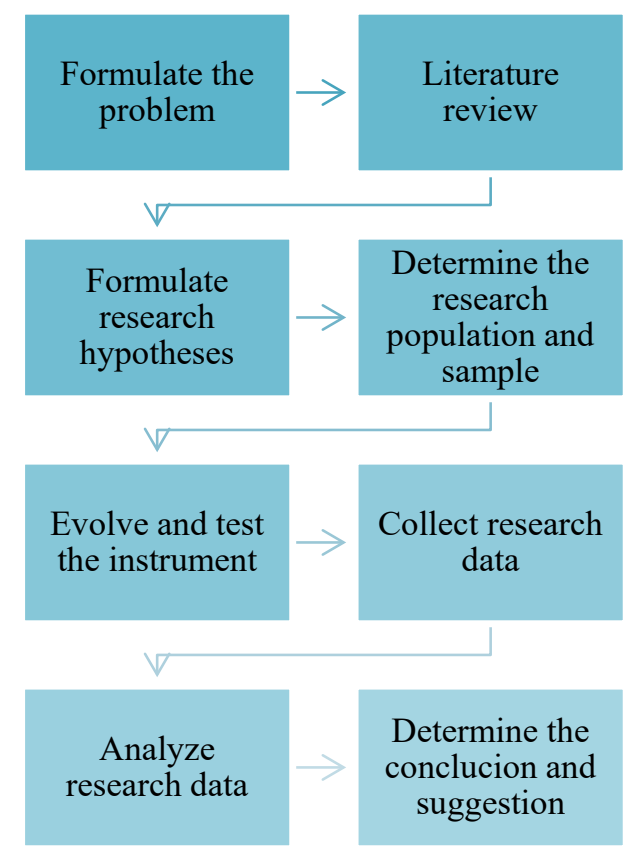

Figure 1. Research Paradigm

The research instrument had been tested for its validity and reliability before being distributed to respondents. The validity of the instrument used construct validity. Construct validity was made based on the relevant theory, consulted with the expert judgment, and continued with factor analysis. The validity test is carried out empirically using the Pearson Product Moment Correlation formula, as in Formula 1. 


$$
R_{x y}=\frac{n\left(\sum_{x i y i}\right)-\left(\sum_{x i}\right) \cdot\left(\sum_{y i}\right)}{\sqrt{n\left(\sum_{x i 2}\right)\left(\sum_{x i}\right)} \sqrt{n}\left(\sum_{y i 2}\right)\left(\sum_{y i 2}\right)}
$$

Notes:

$\mathrm{R}$ xy $=$ correlation coefficient

$\mathrm{X}=$ score for each variable

$\mathrm{Y}=$ score for each respondent

$\mathrm{n}=$ number of respondents

The validity results show that all statement items consisting of three-dimensional descriptions of instructional leadership variables in the form of defining the school's mission, managing instructional programs, and promoting a positive learning climate are declared valid. The first dimension consists of five statement items, the second dimension consists of six statement items, and the third dimension consists of twelve statement items. This is as displayed in Table 2.

Table 2. Validity Results of Instructional Leadership Variable

\begin{tabular}{clcc}
\hline No. & \multicolumn{1}{c}{ Dimension } & Number of Item & Validity Results \\
\hline 1 & Defining school mission & $1-4$ & Valid \\
2 & Managing instructional program & $5-10$ & Valid \\
3 & Promoting a positive school learning climate & $11-22$ & Valid \\
\hline
\end{tabular}

The results of the teacher job satisfaction variable's validity consist of 21 statement items which are the elaboration of nine dimensions in the form of salary, working conditions, promotions, supervision, co-workers, allowances, rewards, communication, and the work itself declared valid. This can be observed in Table 3 .

Table 3. Validity Results of Job Satisfaction Variable

\begin{tabular}{|c|c|c|c|}
\hline No. & Dimension & Number of Item & Validity Results \\
\hline 1 & Salary & 1,2 & Valid \\
\hline 2 & Working condition & $3,4,5,6$ & Valid \\
\hline 3 & Promotion & 7,8 & Valid \\
\hline 4 & Supervision & 9,10 & Valid \\
\hline 5 & Co-workers & 11,12 & Valid \\
\hline 6 & Allowance & 13 & Valid \\
\hline 7 & Rewards & 14,15 & Valid \\
\hline 8 & Communication & 16,17 & Valid \\
\hline 9 & The work itself & $18,19,20,21$ & Valid \\
\hline
\end{tabular}

In this study, the reliability of the instrument was tested by using the internal consistency reliability test. This reliability test is important because the instrument scale items must assess the same basic construction. Therefore these items must have appropriate intercorrelations (Creswell \& Poth, 2018). The formula that is used to determine the reliability is the Cronbach alpha coefficient formula which can be seen in Formula 1. The scale's internal consistency was quantified by Cronbach's alpha $(\alpha)$ values ranging between 0 and 1 , with optimal values ranging between 0,7 , and 0,9 .

The results of the reliability test for the instructional leadership variable showed the value of $\alpha=0,968>0,7$. Therefore the instructional leadership variable is declared reliable. The reliability test results for the teacher job satisfaction variable show the value of $\alpha=0,984>0,7$; therefore, the teacher job satisfaction variable is declared reliable. The researcher is also using simple linear regression analysis to analyze the research data. Simple linear regression analysis is based on a functional or causal relationship between independent and dependent variables (Sugiyono, 2013). The variables to be studied can be arranged in an equation, as can be seen in Formula 2. 


$$
\mathrm{r}_{\mathrm{i}}=\frac{k}{(k-1)}\left\{1-\frac{\sum s_{i}^{2}}{s_{t}^{2}}\right\}
$$

Notes:

$\mathrm{r}_{1}=$ Reliability coefficient instrument

$k=$ The number of questions

$\sum s_{i}^{2}=$ Total variance of items

$s_{t}^{2}=$ Total variance

$$
Y=\alpha+\beta X
$$

Notes:

$Y=$ Dependent variable

$\alpha=$ Constant

$\beta=$ Coefficient of $X$ variable

$X=$ Independent variable

The researcher conducts the hypothesis research through the t-test obtained by calculating the SPSS application version 22, comparing it with the $t$ table, and deciding on the acceptance or rejection of hypothesis 0 (Ho). The hypothesis in this study is formulated as follows: 1.) Ho : $\beta=0$, there are no positive and significant influences on school principal instructional leadership on teacher job satisfaction; and 2.) Ha : $\beta \neq 0$, there are positive and significant influences on school principal instructional leadership on teacher job satisfaction.

\section{RESULT AND DISCUSSION}

The hypothesis test results completed by using SPSS application version 22 reveal the results in Table 4. Based on Table 4 of simple linear regression test results, the regression equation can be determined as in $Y=\alpha+\beta x=18,242+0,640 X \_1$. The constant number of 18,242 indicates that if the instructional leadership variable $(\mathrm{X})$ does not exist, the job satisfaction variable $(\mathrm{Y})$ 's the consistent value 18,242 . The regression coefficient of 0,640 indicates that for every $1 \%$ increase in the instructional leadership variable $(\mathrm{X})$, the teacher job satisfaction variable will increase by 0,640 .

Table 4. Test Results of Simple Linear Regression

\begin{tabular}{ll}
\hline Variable & Instructional Leadership (X) \\
\hline Coefficient $B$ unstandardized & $\alpha: 18.242, \beta: 0.640$ \\
Coefficient $\beta$ standardized & $\beta: 0.816$ \\
$F$ & 177.615 \\
$T$ & 13.329 \\
Significance & 0.000 \\
$R$ & 0.816 \\
$R^{2}$ & 0.666 \\
Notes & Ho rejected, Ha accepted \\
\hline
\end{tabular}

The correlation number $(\mathrm{R})$ of 0,816 and the determination coefficient $\left(\mathrm{R}^{\wedge} 2\right)$ of 0,666 can be interpreted as the instructional leadership variable influencing teacher job satisfaction of $66,6 \%$. Other variables influence the remaining percentage of 33,4\%. The results of hypothesis testing through simple linear regression are calculated by comparing the significant value and comparing the t-test value on the $t$ table.

Based on the guidelines for concluding regression analysis (especially by paying attention to the significant value (Sig.) from the SPSS output), it is explained that if the significance value is less than 0,05 , there is an influence between them the independent variables on the dependent. Meanwhile, if the significant value is greater than 0,05 , there is no influence between the independent 
variable and the dependent variable. The significant number based on Table 4 is $0,000<0,05$; therefore, it can be concluded that Ho is rejected, and Ha is accepted, meaning that there is an influence between the principal instructional leadership variable (X) towards the teacher job satisfaction variable $(\mathrm{Y})$.

The hypothesis test is completed by using a t-test based on the results of SPSS output with decision-making guidelines. If the value of $t$ count $>t$ table, there is an influence between the independent variable and the dependent variable. Whereas, if the value of $t$ count $<t$ table, there is no influence between the independent variable and the dependent variable. The calculated $t$ value can be found in Table 4, while the following Formula 3 obtains the $t$ table value.

$$
\begin{aligned}
& \text { Value } \alpha / 2=0,05 / 2=0,025 \\
& \begin{aligned}
\text { Degrees of freedom }(\mathrm{df}) & =\mathrm{n}-2 \\
& =91-2=89
\end{aligned}
\end{aligned}
$$

Looking at the distribution table of $t$ value, with $\alpha=0,025 ; \mathrm{df}=89$, the $t$ table value that obtained is 1,980. Based on Table 4, it is known that the $t$ count value is $13,329>1,980$. Hence, it can be concluded that Ho is rejected, and Ha is accepted, which means that there is an influence between the instructional leadership variable $(\mathrm{X})$ on the teacher job satisfaction variable $(\mathrm{Y})$. Based on the research results conducted using the questionnaires on 91 samples of vocational high school teachers in Tempel District, it is found that the coefficient of determination $\left(\mathrm{R}^{2}\right)$ between the instructional leadership variable on teacher job satisfaction is 0,666 . $R$ square value of 0,666 can be interpreted that the instructional leadership variable was having an influence on teacher job satisfaction by $66,6 \%$. Other variables influence the remaining percentage of $33,4 \%$.

Furthermore, this study proved the research hypothesis that there is a positive and significant influence between the leadership and teacher job satisfaction variables. This is evidenced by the significant number of $0,000<0,05$ and the t count value of $13,329>1,980$. Therefore, it can be concluded that Ho is rejected, and $\mathrm{Ha}$ is accepted, which means there is a significant and positive influence between the principal instructional leadership variable $(\mathrm{X})$ on the satisfaction variable of teachers' work (Y).

The research questionnaires on instructional leadership contain three dimensions of instructional leadership: defining the school mission, managing instructional programs, and developing the school learning climate. These dimensions are in accordance with the instructional leadership framework proposed by Hallinger (2005). Meanwhile, the research questionnaires on teacher job satisfaction contain nine sub-variables in the form of salary, working conditions, promotions, supervision, co-workers, allowance, rewards, communication, and the work itself. The job satisfaction sub-variable adjusts to the main factors that support job satisfaction according to Gruneberg (1979) in the form of 1.) Salary; 2.) Security; 3.) Workgroup; 4.) Supervision; 5.) Participation; 6.) Role conflict and ambiguity; and 7.) Organizational structure and organizational climate.

The instructional leadership model corresponds to the principal's behavior and practice that is managed to improve teaching and learning activities in schools (Liu, Bellibas, and Gumus, 2020: 4). According to Liu et al. (2020), the principal instructional leadership model is increasingly popular in all parts of the world, which makes several countries have encouraged their principals to implement it. This study's results correspond to research conducted by Aji et al. (2020), which showed a positive influence between instructional leadership and teacher job satisfaction. The results of this study also correspond to the findings by Liu et al. (2020), which revealed that instructional leadership was positively and directly related to teacher job satisfaction.

The results of other studies proposed by Dou et al. (2016) were conducted at 26 Senior High Schools in China with a total of 528 teachers and 59 principals as the respondents showed that there was a significant influence of instructional and transformational leadership on teacher job satisfaction and organizational commitment mediated by the indirect impact of school climate and teacher selfefficacy. The findings of this study at least strengthen those findings that related to instructional leadership and teacher job satisfaction. This study was proved significantly that instructional leadership has an influence on teacher job satisfaction, both as a single variable and when together with teacher self-efficacy and school climate variables. 
The findings of Qadach et al. (2019) revealed other evidence. It revealed that collective teacher self-efficacy and shared vision are the main mediators between the principal instructional leadership and the teacher's intention to leave. This study has a weakness in its inability to identify the relationship between the dependent variables. Therefore, it has not been able to show the more diverse relationship between variables. The research results by Bellibas and Liu (2017) also provided an overview for future research to discover more about the relationship between the instructional leadership variable and the teacher self-efficacy variable, where instructional leadership can predict teacher self-efficacy in three aspects, namely: classroom management, learning management, and student management (Bellibas \& Liu, 2017).

Fathi et al. (2021) of principals' instructional leadership and teacher job satisfaction also included collective teacher self-efficacy conducted on 292 teachers in Iran, which showed that there was a positive relationship between principals' instructional lead-ership, collective teacher efficacy, and teacher job satisfaction. Their study reveals that the principal's instructional leadership has a positive effect on collective teacher efficacy and teacher job satisfaction so that teachers can increase commitment, professional involvement, and job satisfaction in accordance with the character of instructional leadership. In this study, the positive relationship was limited to two variables indicating principal's instructional leadership and teacher job satisfaction so that it can strengthen the finding that principal's instructional leadership has a significant effect on teacher job satisfaction.

The findings which in line with this research shown by Anub (2020), who proves that the instructional leadership carried out by the principal has a positive effect on teacher job satisfaction and school performance indicators. The results of the research conducted by Sindhvad et al. (2020) on the factors that affect the principal's instructional leadership capacity showed that any improvement in the instructional leadership practices carried out by the principal will increase the principal's intention to implement instructional leadership. School principals need to provide separate time for the implementation of effective instructional leadership (Sindhvad et al., 2020). Principals' instructional leadership practices are believed to improve the principal's leadership function (Sindhvad et al., 2020). This study indicates that principals carry out instructional leadership practices to affect teacher job satisfaction positively. As revealed by Bada et al. (2020), other findings also show that the principal's instructional leadership has a positive effect on the effectiveness of teachers at work.

\section{CONCLUSION}

Based on the data that have been analyzed and discussed with 30 respondents of culinary art subject teachers, the following conclusions can be drawn: 1.) The aspect of novelty related to new dishes, new cooking utensils, and new businesses in the culinary field can be given by teachers through teaching preparation, materials, methods, learning resources, and teaching media. This aspect relates to openness to reforming and thinking attitude as a beginner, which is in accordance with the nature of attention in teaching culinary art in vocational high schools. It is in a good category, with a percentage of $53.33 \%$; 2.) Teachers can make the aspects of variation on information in teaching through teaching preparation, materials, methods, learning resources, and teaching media. This aspect relates to being alert and sensitive to contextual differences and perspectives that can increase creativity in teaching culinary art in vocational high school. It is in a good category, with a percentage of $66.67 \%$; 3.) Teachers can apply the joyfulness aspect by knowing students' personalities through teaching methods and media. This aspect is able to change the mindset of work into a game and appreciate every moment of teaching in vocational high school. It is in a very good category, with a percentage of $60 \%$; 4.) The teacher can carry out the aspect of meaningfulness through preliminary, core, and closing activities. This aspect relates to the student's personality, which can be applied through meaningful learning and discovery learning so as to increase the students' confidence in learning culinary art in vocational high school. It is in a very good category with a percentage of $76.67 \%$; and 5.) The teacher carries the aspect of alertness in the preliminary, core, and closing activities. This aspect can encourage alertness and sensitivity to different perspectives according to sideways learning when teaching the theory and practice of culinary art in vocational high schools. It is in a very good category, with a percentage of $70 \%$. 
Based on the conclusions above, the implications are as follows: 1.) Teaching in the field of culinary expertise is more open to novelty. The students are encouraged to learn about new things in the culinary field; 2.) Teaching in the field of culinary expertise is more varied. The students are encouraged to learn many differences in the culinary field rather than learning about one thing; 3. ) Learning in the field of gastronomy is more fun so that students do not feel burdened when learning gastronomy; 4.) Learning in the field of culinary expertise becomes more meaningful. The students are encouraged to link learning with their lives; and 5.) Learning in the field of culinary expertise is more alert. The students are always encouraged to be aware of differences in material as well as those in learning the theory and practice.

Based on the research, the following suggestions are made: 1.) Teachers can develop teaching activities starting from lesson planning, introduction, core, and closing activities by paying attention to the aspects of novelty, variety, joyfulness, meaningfulness, and alertness in learning; and 2.) The government, education offices, schools, and related stakeholders can assist teachers by creating training programs related to mindfulness learning.

\section{REFERENCES}

Aji, A., Qowaid, Q., \& Faqihuddin, M. (2020). Pengaruh kepemimpinan instruksional dan iklim sekolah terhadap kepuasan kerja guru pada Sekolah Dasar Negeri se-Kecamatan Pamijahan Kabupaten Bogor. Reslaj: Religion Education Social Laa Roiba Journal, 2(2), 197-205. https://doi.org/10.47467/reslaj.v1i2.109

Anub, C. D. (2020). Instructional leadership practices, teachers' satisfaction and school performance indicators. Journal of World Englishes and Educational Practices (JWEEP), 2(4), 50-64. https://doi.org/10.32996/jweep.2020.2.4.6

Bada, H. A., Tengku Ariffin, T. F., \& Nordin, H. B. (2020). The effectiveness of teachers in Nigerian secondary schools: The role of instructional leadership of principals. International Journal of Leadership in Education, 1-28. https://doi.org/10.1080/13603124.2020.1811899

Baluyos, G. R., Rivera, H. L., \& Baluyos, E. L. (2019). Teachers' job satisfaction and work performance. Open Journal of Social Sciences, 7(8), 206-221. https://doi.org/10.4236/jss.2019.78015

Bellibas, M. S., \& Liu, Y. (2017). Multilevel analysis of the relationship between principals' perceived practices of instructional leadership and teachers' self-efficacy perceptions. Journal of Educational Administration, 55(1), 49-69. https://doi.org/10.1108/JEA-12-20150116

Buluc, B., \& Demir, S. (2015). The relationship between job satisfaction and self efficacy based on elementary and middle school teacher's perceptions. Journal of Kırşehir Education Faculty, $16(1)$, 289-308. https://www.researchgate.net/publication/314208440_The_Relationship_between_Job_Sati sfaction_and_Self_Efficacy_based_on_Elementary_and_Middle_School_Teacher\% $\% 27 \mathrm{~s}$ _Pe rceptions_Ilk_ve_Ortaokul_Ogretmenlerinin_Oz-

Yeterlik_Algilari_ile_Is_Doyumlari_Arasindaki

Cansoy, R., Polatcan, M., \& Parlar, H. (2018). Research on teacher self-efficacy in Turkey: 20002017. World Journal of Education, 8(4), 133-145. https://doi.org/10.5430/wje.v8n4p133

Creswell, J. W., \& Poth, C. N. (2018). Qualitative inquiry \& researcg design: Choosing among five approaches (4th ed.). SAGE Publications Inc.

Dou, D., Devos, G., \& Valcke, M. (2016). The effects of autonomy gap in personnel policy, principal leadership and teachers' self-efficacy on their organizational commitment. Asia Pacific Education Review, 17(2), 339-353. https://doi.org/10.1007/s12564-016-9428-7

Fathi, J., Ahmadnejad, M., \& Salehi, M. (2021). An investigation of the relationship among principal instructional leadership, collective teacher efficacy and teacher job satisfaction: A structural 
equation modeling approach. Journal of School Administration, 9(2), 1-25. https://jsa.uok.ac.ir/article_61875.html

Gruneberg, M. M. (1979). Understanding job satisfaction. Wiley.

Hallinger, P. (2005). Instructional leadership and the school principal: A passing fancy that refuses to fade away. Leadership and Policy in Schools, 4(3), 221-239. https://doi.org/10.1080/15700760500244793

Hallinger, P., \& Wang, W.-C. (2015). Assessing instructional leadership with the principal instructional management rating scale. Springer. https://doi.org/10.1007/978-3-319-155333

Hulmawiyah, H., Hariani, L. S., \& Yudiono, U. (2018). Pengaruh kepemimpinan kepala sekolah, disiplin kerja dan kompensasi terhadap kepuasan kerja guru. Jurnal Riset Pendidikan Ekonomi, 3(1), 1-10. https://doi.org/10.21067/jrpe.v3i1.3810

Liu, Y., Bellibaş, M. Ş., \& Gümüş, S. (2020). The effect of instructional leadership and distributed leadership on teacher self-efficacy and job satisfaction: Mediating roles of supportive school culture and teacher collaboration. Educational Management Administration \& Leadership, 49(3), 430-453. https://doi.org/10.1177/1741143220910438

Locke, E. A. (1969). What is job satisfaction? Organizational Behavior and Human Performance, 4(4), 309-336. https://doi.org/10.1016/0030-5073(69)90013-0

Nuraini, A., Yuwariah, Y., \& Rochayat, Y. (2015). Pengembangan produksi pertanian lahan kering dengan sistem Low External Input Sustainable Agriculture (LEISA) di Desa Cigadog, dan Mandalagiri Kecamatan, Leuwisari Kabupaten Tasikmalaya. Dharmakarya : Jurnal Aplikasi Ipteks Untuk Masyarakat, 4(2), 113-118. https://doi.org/10.24198/dharmakarya.v4i2.10037

Özdemir, G., Şahin, S., \& Öztürk, N. (2020). Teachers' self-efficacy perceptions in terms of school principal's instructional leadership behaviours. International Journal of Progressive Education, 16(1), 25-40. https://doi.org/10.29329/ijpe.2020.228.3

Qadach, M., Schechter, C., \& Da'as, R. (2019). Instructional leadership and teachers' intent to leave: The mediating role of collective teacher efficacy and shared vision. Educational Management Administration \& Leadership, 48(4), 617-634. https://doi.org/10.1177/1741143219836683

Rahayuningrum, C., Sutaryadi, S., \& Hardjant, P. N. (2019). Pengaruh gaji dan lingkungan kerja non fisik terhadap kepuasan kerja guru di SMK PENDA 2 Katanganyar. JIKAP (Jurnal Informasi Dan Komunikasi Administrasi Perkantoran), 3(2), 41-48. https://jurnal.uns.ac.id/JIKAP/article/view/21992

Setyosari, P. (2014). Menciptakan pembelajaran yang efektif dan berkualitas. JINOTEP (Jurnal Inovasi Dan Teknologi Pembelajaran): Kajian Dan Riset Dalam Teknologi Pembelajaran, 1(1), 20-30. https://doi.org/10.17977/um031v1i12014p020

Sindhvad, S., Mikayilova, U., \& Kazimzade, E. (2020). Factors influencing instructional leadership capacity in Baku, Azerbaijan. Educational Management Administration \& Leadership, 20(10), 1741143220938364. https://doi.org/10.1177/1741143220938364

Skaalvik, C. (2020). School principal self-efficacy for instructional leadership: relations with engagement, emotional exhaustion and motivation to quit. Social Psychology of Education, 23(2), 479-498. https://doi.org/10.1007/s11218-020-09544-4

Smith, W. F., \& Andrews, R. L. (1989). Instructional leadership: How principals make a difference. Association for Supervision and Curriculum Development. https://files.eric.ed.gov/fulltext/ED314826.pdf

Spector, P. E. (1997). Job satisfaction: Application, assessment, causes, and consequences. Sage Publications. 
Sugiyono, S. (2013). Metode penelitian pendidikan: Pendekatan kuantitatif, kualitatif, dan $R \& D$ (17th ed.). Alfabeta.

Türkoğlu, M. E., Cansoy, R., \& Parlar, H. (2017). Examining relationship between teachers' selfefficacy and job satisfaction. Universal Journal of Educational Research, 5(6), 765-772. https://doi.org/10.13189/ujer.2017.050509 